\section{Harvest and Postharvest Quality of Short-day Onions in Variety Trials in Georgia, 2000-03}

\author{
George E. Boyhan ${ }^{1}$, Albert C. Purvis ${ }^{2}$, William M. Randle ${ }^{3}$, \\ Reid L. Torrance ${ }^{4}$, M. Jefferson Cook IV ${ }^{5}$, Greg Hardison ${ }^{6}$, \\ Ronald H. Blackley ${ }^{6}$, Heath Paradice ${ }^{7}$, C. Randy Hill ${ }^{8}$, and \\ J. Thad Paulk ${ }^{9}$
}

Additional Index wORDs. Allium cepa, Vidalia, spring onions, non-storage onions, controlled-atmosphere storage, pyruvate, soluble solids

Summary. Short-day onion (Allium cepa) variety trials were conducted in southeastern Georgia from 2000-03. Data collected and evaluated included total yield, graded yield, harvest date, number of seedstems, number of doubles, number of onion centers, bulb shape, disease incidence, bulb pungency, and storability in controlled atmosphere (CA) storage. Fifty-eight varieties were evaluated in the trials with 10 varieties appearing in all 4 years. Twenty-nine varieties appeared only once in the trials. Eight varieties had jumbo yields ( $\geq 3$-inch diameter) that were not significantly different from the greatest jumbo yielding variety in 2 of the 4 years of testing and included 'Century', 'EX 19013', 'Georgia Boy', 'Mr. Buck', 'Sapelo Sweet', 'Savannah Sweet', 'Sweet Vidalia', and 'WI-609'. Early season varieties were strongly daylength dependent with foliar lodging occuring early and uniformly. Late season varieties were more prone to bacterial infection particularly if postharvest heat curing was employed. Although significant differences between varieties for seedstems (flower formation) and bulb doubling occurred almost every year, environmental conditions were an important part of their development. Five varieties had seedstems in 2 of the 3 years seedstems were prevalent that did not differ from the greatest number of seedstems for that year and included 'Cyclops', 'Georgia Boy', 'Mr. Buck', 'Pegasus', and 'SSC 6372 $\mathrm{F}_{1}$ '. 'Sapelo Sweet' and 'Sweet Advantage' had more than $\mathbf{5 \%}$ bulb doubling in 3 years of the trials. Pungency as measured by pyruvate analysis ranged from 1.1 to $5.4 \mu \mathrm{mol} \cdot \mathrm{g}^{-1}$ fresh weight (FW) over the 4 years of trials. There were nine varieties that were, for 2 years or more, among the greatest in percent marketable onions after 4.5 months of CA storage: 'Georgia Boy', 'Granex 1035', 'Granex 33', 'Ohoopee Sweet', 'Sapelo Sweet', 'Savannah Sweet', 'Sweet Melissa', 'Sweet Melody', and 'SRO 1000'.

S hort-day onion production in southeastern Georgia is an important part of the agricultural economy with a farm gate value that has ranged from about $\$ 70$ million to over $\$ 94$ million in the last 4 years
(Doherty et al., 2002). This region of Georgia is characterized by mild winters, low sulfur, sandy loam soils, and abundant irrigation water. Its proximity to the Atlantic Ocean moderates winter temperatures so they rarely are below

\footnotetext{
${ }^{1}$ Associate Professor, Extension Horticulturist-Vegetables, Univ. of Georgia, Dept. of Horticulture, East Georgia Extension Center, P.O. Box 8112, GSU, Statesboro, GA 30460; to whom reprint requests should be addressed; e-mail: gboyhan@uga.edu

${ }^{2}$ Professor Emeritus, Univ. of Georgia, Dept. of Horticulture, Coastal Plain Experiment Station, P.O. Box 748, Tifton, GA 31793.

${ }^{3}$ Professor, Univ. of Georgia, Dept. of Horticulture, 1111 Plant Science Bldg., Athens, GA 30602

${ }^{4}$ County Extension Coordinator, Tattnall County Cooperative Extension Service, P.O. Box 580, Reidsville, GA 30453.

${ }^{5}$ County Agent, Tattnall County Cooperative Extension Service, P.O. Box 580, Reidsville, GA 30453.

${ }^{6}$ Former County Extension Coordinator, 432 TyTy Omega Road, Tifton, GA 31793. Currently Field Trial Coordinator-Seminis.

${ }^{7}$ County Agent, Treutlen County Extension Service, 206 Third St., Soperton, GA 30457.

${ }^{8}$ Farm Superintendent, Vidalia Onion and Vegetable Research Center, 8163 Hwy. 178, Lyons, GA 30436 .

${ }^{9}$ Agricultural Research Assistant, Univ. of Georgia, Dept. of Horticulture, Coastal Plain Experiment Station, P.O. Box 748, Tifton, GA 31793
}

freezing. Sulfur is known to increase onion pungency and the low sulfur soils in southeastern Georgia are particularly well suited to production of mild onions (Granberry et al., 1987). Finally, the abundant irrigation water from the Floridan aquifer contributes to the production of large mild onions. The importance of this industry has led seed companies to develop new varieties suitable to this region. Growers are interested in the yield and quality of new varieties. Variety trial evaluations under appropriate statistical controls can provide needed information to both seed companies and growers.

Vegetable variety trials have continued to be important to a number of stakeholders, including researchers, growers, and seed companies. There has been some concern as to the reduced resources in vegetable variety trials in some states, but there have also been increased support in others (Maynard, 2002; Williams and Roberts, 2002). Variety trials involving onions have been conducted worldwide, including Europe, Australia, India, and Russia, as well as in several locations in the U.S., including Texas, Georgia, and Florida (Boyhan et al., 2001; Ergeshova, 1987; Fuqua and Howell, 1975; Lallan Singh et al., 1992; Maynard, 1989; Quadir et al., 2002; Schiavi et al., 2002).

Onion trials have examined a number of different performance parameters, not the least of which is yield. Along with yield, onion variety trials have been conducted to examine storability, suitability for dehydration, disease resistance, suitability for mechanical harvesting, and adaptation for production under saline conditions (Cramer, 2001; Silue et al., 2003; Vasetskii and Reznik, 1990; Verma et al., 1999; Zuev et al., 1974).

Onions are unique in being highly regionally adapted, primarily due to daylength response, although mild temperatures are also important. Daylength dependence of bulbing has

\begin{tabular}{llll}
\hline $\begin{array}{l}\text { Units } \\
\text { To convert } \\
\text { U.S. to SI, } \\
\text { multiply by }\end{array}$ & U.S. unit & SI unit & $\begin{array}{l}\text { To convert } \\
\text { SI to U.S., } \\
\text { multiply by }\end{array}$ \\
\hline 0.4047 & acre $(\mathrm{s})$ & $\mathrm{ha}$ & 2.4711 \\
0.3048 & $\mathrm{ft}$ & $\mathrm{m}$ & 3.2808 \\
9.3540 & $\mathrm{gal} / \mathrm{acre}$ & $\mathrm{L} \cdot \mathrm{ha}^{-1}$ & 0.1069 \\
2.5400 & inch $(\mathrm{es})$ & $\mathrm{cm}$ & 0.3937 \\
0.4536 & $\mathrm{lb}$ & $\mathrm{kg}$ & 2.2046 \\
1.1209 & $\mathrm{lb} / \mathrm{acre}$ & $\mathrm{kg} \cdot \mathrm{ha}^{-1}$ & 0.8922 \\
2.3385 & $\mathrm{qt} / \mathrm{acre}$ & $\mathrm{L} \cdot h a^{-1}$ & 0.4276 \\
$\left({ }^{\circ} \mathrm{F}-32\right) \div 1.8$ & ${ }^{\circ} \mathrm{F}$ & ${ }^{\circ} \mathrm{C}$ & $\left(1.8 \times{ }^{\circ} \mathrm{C}\right)+32$ \\
& & &
\end{tabular}


been known since the 1920s and onions are often classified as either short-day, intermediate-day, or long-day (Brewster, 1994). Therefore, for onion variety trials to be meaningful, they must be conducted in the region where the tested varieties will be grown.

Short-day onions, for example, are adapted to those regions falling between $35^{\circ}$ north and south latitudes and have mild winters. These onions typically bulb when daylengths begin to exceed $1 \mathrm{l}-12 \mathrm{~h}$, whereas intermediate and long-day onions require $13-14$ and 16 h, respectively (Brewster, 1994).

Even within a specific daylength group, varieties often are locally adapted for color, shape, and specific production practices. In southeastern Georgia, there are also restrictions on the type of onion that can be grown and marketed with the Vidalia trademark (Boyhan and Torrance, 2002). Onion varieties that are to be marketed as Vidalia onions must be tested and recommended by the University of Georgia to be included (or to remain) on the Georgia Department of Agriculture's approved Vidalia onion variety list. Onion varieties in the $\mathrm{Vi}$ dalia growing region of southeastern Georgia must be Granex-type, yellow onions. In addition, shape, pungency, sugar content, as well as other characteristics as deemed appropriate by the Director of the Experiment Station of the University of Georgia, are used to determine the suitability of new onion varieties (State of Georgia, 2004). The area of production and the variety type restrictions are enforced by both the state, which owns the Vidalia name for purposes of marketing onions, and Federal market order 995 (Boyhan et al., 2002). Examples of varieties on the official Georgia Department of Agriculture list are 'Sugar Belle $\mathrm{F}_{1}$ ','Savannah Sweet', and 'Pegasus', representing early, mid-season, and late varieties, respectively.

The objectives of these trials were to evaluate the performance of short-day onions in the Vidalia growing region of southeastern Georgia. Information on total yield, graded yield, harvest date, disease resistance, physiological problems, flavor, and controlled atmosphere storability were measured.

\section{Materials and methods}

Trials were conducted at the Vidalia Onion and Vegetable Research
Center (VOVRC) in Lyons, Ga. (lat. $32^{\circ} 11^{\prime} \mathrm{N}$, long. $\left.82^{\circ} 17^{\prime} \mathrm{W}\right)$. Onion production followed University of Georgia Cooperative Extension Service recommendations. Typical production began in August with land preparation for plantbed (transplants) onion production and fumigation with 60 gal/acre of $42 \%$ metam sodium. Eight hundred pounds/acre of 5-10-15 with $9 \%$ sulfur $(5 \mathrm{~N}-4.4 \mathrm{P}-12.4 \mathrm{~K}-9 \mathrm{~S})$ fertilizer was incorporated prior to final bed formation. Beds were formed on 6-ft centers and abut 4-6 inches high. Chlorpyrifos insecticide (1 qt/acre) was applied to the beds as a final step prior to seeding. Four rows with 12 inch between-row spacing were seeded at a high density of 30-70 seeds/ft of row in the third week of September. Immediately after seeding, $150 \mathrm{lb} /$ acre of $18-46-0(18 \mathrm{~N}-20.1 \mathrm{P}-0 \mathrm{~K})$ was topdressed on the bed. This was followed by $200 \mathrm{lb} /$ acre of $\mathrm{Ca}\left(\mathrm{NO}_{3}\right)_{2}$ applied at 4 and 6 weeks after seeding. Weed control consisted of chlorthal dimethyl applied preemergent at $3-3.75 \mathrm{lb} /$ acre a.i. followed by applications of oxyfluorfen at $0.05 \mathrm{lb} /$ acre a.i. at the twoand four-leaf stages. Disease control began immediately after emergence with applications of chlorothalonil and/or mancozeb at recommended rates applied every $7-14 \mathrm{~d}$ depending on disease pressure and environmental conditions. Copper-based fungicides were also used if bacterial diseases were suspected of being present. Transplants were ready 8-10 weeks after seeding and were pulled, bundled, and had about $50 \%$ of their tops removed. Transplanting occurred from the end of November to mid-December.

Prior to transplanting, $400 \mathrm{lb} /$ acre of 5-10-15 with $9 \%$ sulfur was preplant incorporated. Beds were formed and chlorpyrifos insecticide applied as described above. A pegger with a gang of four spiked wheels was used during final bed preparation. These wheels have welded steel pegs set for an in-row spacing of 5.5 inches and are set 12 inches apart. These pegs form a hole about 2 inches deep for the transplants. Subsequently, onions were transplanted into these holes for a population of 63,360 plants/acre.

Six weeks after transplanting, $150 \mathrm{lb} /$ acre of 18-46-0 fertilizer was broadcast on the beds. This was followed by $200 \mathrm{lb} /$ acre of 6-12-18 with $5 \%$ sulfur fertilizer at 8 and 10 weeks after transplanting. $\mathrm{Ca}\left(\mathrm{NO}_{3}\right)_{2}$ was applied at $200 \mathrm{lb} /$ acre, 13 and 15 weeks after transplanting.

After transplanting, weed control consisted of $0.375 \mathrm{lb} /$ acre a.i. of oxyfluorfen and $0.625 \mathrm{lb} /$ acre a.i. of pendimethalin herbicide applied within 4 weeks after transplanting during suitable weather favoring rapid evaporation. Disease control began 6-8 weeks after transplanting with applications at manufacturers' recommendations of chlorothalonil, moncozeb, iprodione, azoxystrobin, copper fungicides, or similar products at 7 - to 14 -d intervals depending on weather conditions, pathogens, and disease pressure.

Onions were considered mature when there was significant weakness in the onion necks and/or approximately $20 \%$ to $50 \%$ foliar lodging. Onions from each plot were pulled and laid on the ground and allowed to field dry for $2 \mathrm{~d}$, at which time the foliage was removed 2 inches above the bulb and the roots removed. Harvest dates indicate when onions were first pulled. Onions were placed in mesh bags and weighed in the field, which is the reported total yield. They were then heat cured for $2-5 \mathrm{~d}$ at $95^{\circ} \mathrm{F}$ before being graded into size classes and weighed. Depending on variety and year, harvest occurred between the first week of April and mid-May.

Twenty-eight entries were included in the 1999-2000 trial. Plantbeds were sown on 23 Sept. 1999. A Stanhay Precision Planter model 5870 (Stanhay Webb, Grantham, U.K.) was used with belts punched with a double row of holes set approximately 0.5 inch apart. Plants were transplanted on 23 Nov. 1999 to their final spacing.

Plots consisted of 50 -ft-long sections of bed with a 5 - $\mathrm{ft}$ alley between each adjacent plot in-row. The experimental design was a randomized complete-block design (RCBD) with four replications. Bulb doubles, seedstems, and center rot (Pantoea ananatis) bacterial incidence were recorded on 4 Apr. 2000.

Thirty feet of bed from each plot was harvested when the specific variety was judged mature. Based on maturity, onions were harvested on $6,12,19$, 26 Apr. and 4, 11 May 2000.

Harvested onions from each plot were graded into size classes consisting of small ( $<2.5$ inches), medium $(\geq 2.5$ and $<3$ inches), large ( $\geq 3$ and $\leq 3.5$ inches), and jumbo (>3.5 inches). Only medium, large, and jumbo are reported 
with large and jumbo combined into a jumbo class to conform with USDA grade standards for Granex onions (USDA, 1995a). Culls, which are not reported, consisted of small onions, damaged, and diseased onions that were removed during the grading process.

Approximately $50 \mathrm{lb}$ of graded onions from each plot was weighed and then placed in controlled atmosphere (CA) storage [ $5 \%$ carbon dioxide, $3 \%$ oxygen, $34^{\circ} \mathrm{F}, 70 \%$ relative humidity $(\mathrm{RH})$ ] with each replication placed in a separate CA room at the Vidalia Onion Research Laboratory (VORL) in Tifton, Ga. Onions were removed from CA storage on 10 Oct. 2000 at which time they were sorted into marketable and unmarketable onions and weighed with any diseases noted and recorded.

A five-bulb sample from each plot was measured after removal from CA storage for bulb width and depth. Depth was measured from the basal plate distally to where the leaves were attached. Width was measured perpendicular to the depth at the widest point.

In the 2000-01 growing season there were 28 entries. The plot size and experimental arrangement was as described above. Plantbeds were sown on 25 Sept. 2000 with a Monosem vacuum planter (model 540; ATI, Lenexa, Kans.) with a 190-hole plate set to sow double rows for each hopper with an in-row spacing of $3 / 8$ inch. Plantbed onions were transplanted on 27 Nov. 2000 to their final spacing. The number of bulb doubles and seedstems was recorded on 10 Apr. 2001 for each 50 -ft plot.

Twenty-five feet of each plot was harvested for yield and postharvest data. Onions were harvested from each plot when mature as described above. Harvests occurred on 19, 26 Apr. and 3, 10 May 2001.

Harvested onions were processed as described above and graded into two classes, jumbos ( $\geq 3$ inches) and mediums ( $\geq 2$ and $<3$ inches). Samples from each plot were transported to the VORL for CA storage as described above. Onions were placed in CA on 16 May 2001 and removed on 2 Oct. 2001. After removal from CA storage, onions were sorted into marketable and unmarketable onions and weighed.

During the 2001-02 season there were 31 entries in the trial. Plantbeds were sown on 27 Sept. 2001 and were transplanted to their final spacing on 26 Nov. 2001. Planting and experimental arrangement was as described above. Seedstems and bulb doubles were recorded for each $50-\mathrm{ft}$ plot on 26 Mar. 2002.

A 25 -ft section of each plot was harvested when the onions were judged mature. Harvests occurred on 15, 19, 25 Apr. and 2 May 2002. Onions were processed, graded, and data recorded as described above with grade sizes of medium and jumbo as described from the 2000-01 season. A sample from each plot was transported to the VORL for CA storage as described above. Onions were placed in CA storage on 16 May 2002 and removed on 7 Oct. 2002 and processed as described above, noting incidence of specific diseases and occurrence of sprouting.

Five bulbs from each plot were measured for width and height as described above after removal from CA storage. In addition, onions were also cut in half perpendicular to the growing axis and the number of centers counted. Measurements were made on 15 Oct. 2002.

In addition, onions from each plot judged to be marketable were held at room temperature $\left(\sim 75^{\circ} \mathrm{F}\right)$ for $14 \mathrm{~d}$, until 21 Oct. 2002, and reassessed for marketable and non-marketable onions. In addition, the presence of specific diseases and the number of sprouted onions were noted.

A fourth trial was conducted in the 2002-03 season with 30 entries. Bed preparation and in-row alleys were as reported in previous years, but the length of the plots was $35 \mathrm{ft}$. Seed were sown on the plantbeds on $20 \mathrm{Sept}$. 2002. Transplanting occurred on 3 Dec. 2002. Seedstems, bulb doubles, and plant stand were recorded on 25 Mar. 2003.

Twenty-five feet of each plot was harvested as described previously with harvests occurring on $7,14,21,30$, Apr. and 5, 12 May 2003. Onions were processed and graded as noted in the 2001 and 2002 trials except heat curing was not done with onions harvested on 5 and 12 May 2003 to minimize the incidence of bacterial diseases.

A sample from each plot was placed in CA storage on 19 May 2003 at the VORL as described above, until 1 Oct. 2003 when they were removed and processed as described above. In addition, onions were held at room temperature $\left(\sim 75^{\circ} \mathrm{F}\right)$ until 16 Oct.
2003 when they were reassessed as described for the previous season.

A 10-bulb sample from each plot for each trial was analyzed for pungency using the pyruvate test and reported as micromoles per gram fresh weight (Randle and Bussard, 1993).

All count data, with the exception of bulb centers in 2002, were transformed with square root $(\mathrm{x}+$ $0.5)$. All percent data, with the exception of CA storage data in 2003, were transformed with arcsine [square root (x)] prior to analyses. Reported values were back transformed to their original units. Bulb centers in 2002 were transformed with square root $(\mathrm{x})$ to prevent negative numbers when back transformed to original numbers. In addition, the CA storage values in 2003 were transformed with square $\operatorname{root}(\mathrm{x})$ since the percentage range was less than 40 (Little and Hills, 1978).

Data were subjected to analysis of variance and Fisher's protected least significant difference (LSD) $(P \leq$ 0.05 ) with Bonferroni adjustment to make five comparisons was computed (Pagano and Gauvreau, 2000). Bonferroni adjustment divides the probability by the number of comparisons before computing the LSD. In addition, the coefficient of variation $(\mathrm{CV})$ for each analysis is reported.

\section{Results and discussion}

The total yield of onions harvested in 2000 ranged from 20,370 to $57,142 \mathrm{lb} /$ acre, with 'Savannah Sweet' having the greatest total yield, which was significantly greater than 'Yellow Granex Improved' with a yield of $46,137 \mathrm{lb} /$ acre (Table 1). 'Sweet Melissa' had the greatest jumbo yield at $36,965 \mathrm{lb} /$ acre, which was significantly greater than 'WI-3115' with jumbo yield of $28,108 \mathrm{lb} /$ acre. The greatest medium yields were for 'Sweet Advantage' with 13,867 lb/acre, which was significantly more than 'Sugar Belle $\mathrm{F}_{1}$ ' with $10,079 \mathrm{lb} /$ acre.

The greatest total yield in 2001 was $45,491 \mathrm{lb} /$ acre for 'Century', which was significantly greater than 'Sweet Success' with 38,928 lb/acre (Table 2). 'Century' also had the greatest yield of jumbo onions with $38,754 \mathrm{lb} /$ acre, which was significantly greater than 'PS 7292' with 31,479 $\mathrm{lb} / \mathrm{acre}$. The greatest yield of medium class onions was with 'Southern Belle,' which also had one of the lowest total yields overall. 
Table 1. Short-day onion varieties, their source, date of harvest, total yield at harvest, and cured, graded jumbo, and medium yields for the 1999-2000 season.

\begin{tabular}{|c|c|c|c|c|c|}
\hline Variety $^{\mathrm{y}}$ & Seed source ${ }^{\mathrm{x}}$ & Harvest date & $\begin{array}{l}\text { Total yield } \\
(\text { lb/acre })^{w}\end{array}$ & $\begin{array}{c}\mathrm{Jumbo}^{z} \\
(\mathrm{lb} / \mathrm{acre})^{\mathrm{w}}\end{array}$ & $\begin{array}{l}\text { Medium }^{\mathrm{z}} \\
(\mathrm{lb} / \text { acre })^{\mathrm{w}}\end{array}$ \\
\hline Savannah Sweet & Seminis (Petoseed) & 4 May & 57,142 & 21,308 & 1,053 \\
\hline Georgia Boy (DPS 1032) & D. Palmer Seed & 19 Apr. & 51,340 & 34,461 & 8,240 \\
\hline Sweet Success & Nunhems (Sunseeds) & 4 May & 50,844 & 17,860 & 2,130 \\
\hline Sweet Vidalia & Nunhems (Sunseeds/Rio Colorado) & 26 Apr. & 49,374 & 34,001 & 5,312 \\
\hline Sapelo Sweet (DPS 1039) & D. Palmer Seed & 19 Apr. & 48,164 & 35,514 & 5,651 \\
\hline Mr. Buck (DPS 1033) & D. Palmer Seed & 11 May & 46,857 & 14,847 & 2,444 \\
\hline Granex 33 & Seminis (Asgrow) & 4 May & 46,391 & 14,084 & 2,057 \\
\hline Yellow Granex Imp. (Sun $\mathrm{F}_{1}$ ) & Nunhems (Sunseeds) & 26 Apr. & 46,137 & 26,027 & 4,223 \\
\hline Sweet Melody & Nunhems (Sunseeds/Rio Colorado) & 26 Apr. & 44,637 & 23,970 & 5,342 \\
\hline PS 7092 & Seminis (Petoseed) & 19 Apr. & 41,297 & 24,127 & 9,704 \\
\hline Sweet Advantage (DPS 1058) & D. Palmer Seed & 12 Apr. & 37,135 & 18,416 & 13,867 \\
\hline Georgia Pride $\mathrm{F}_{1}$ & Shamrock & 6 Apr. & 37,038 & 22,167 & 9,874 \\
\hline King Midas (RCS 1919) & Nunhems (Sunseeds/Rio Colorado) & 12 Apr. & 35,822 & 20,255 & 11,507 \\
\hline Sweet Sun & Nunhems (Sunseeds) & 4 May & 34,219 & 8,647 & 4,614 \\
\hline SSC $6372 \mathrm{~F}_{1}$ & Shamrock & 12 Apr. & 32,712 & 15,742 & 12,439 \\
\hline Nikita & Nunhems (Sunseeds/Rio Colorado) & 4 May & 27,503 & 7,696 & 4,005 \\
\hline Evita $\mathrm{F}_{1}$ & Shamrock & 11 May & 26,130 & 3,001 & 1,004 \\
\hline Pegasus & Seminis (Asgrow) & 11 May & 24,164 & 4,175 & 750 \\
\hline Centaur & Seminis (Asgrow) & 11 May & 21,998 & 339 & 24 \\
\hline $1015 Y$ & Seminis (Asgrow) & 11 May & 20,370 & 4,041 & 1,053 \\
\hline
\end{tabular}

${ }^{2}$ Jumbo $=\geq 3$ inches $(7.6 \mathrm{~cm})$, medium $=\geq 2$ and $<3$ inches $(5.1$ and $7.6 \mathrm{~cm})$.

y Name in parentheses is original seed company designation.

${ }^{x}$ Name in parentheses was original seed company that was either acquired or merged with parent company: Seminis = Seminis Vegetable Seeds, Oxnard, Calif.; Nunhems = Nunhems USA, Parma, Idaho; D. Palmer Seed = D. Palmer Seed Co., Yuma, Ariz.; Wannamaker = Wannamaker International, St. Matthews, S.C.; Shamrock = Shamrock Seed Co., Salinas, Calif.

" $1 \mathrm{lb} /$ acre $=1.1209 \mathrm{~kg} \cdot \mathrm{ha}^{-1}$.

"Fisher's protected least significant difference with Bonferroni adjustment to make five comparisons.

Total yield in 2002 ranged from 25,098 to $42,653 \mathrm{lb} /$ acre (Table 3 ). The greatest yielding variety for total yield was 'Mr. Buck', which was significantly greater than 'PS 7092' at $28,953 \mathrm{lb} / \mathrm{acre}$. The greatest yielding variety for jumbos was 'Sapelo Sweet' with 29,134 lb/acre, which was significantly greater than 'Southern Belle' at $15,014 \mathrm{lb} / \mathrm{acre}$. The greatest yielding variety for mediums was 'Sweet Advantage' with $6,931 \mathrm{lb} /$ acre, which was significantly greater than 'Southern Belle' with 4,690 lb/acre.

The harvest in 2003 ranged from $45,564 \mathrm{lb} /$ acre for 'SRO 1001 ' to $15,849 \mathrm{lb} /$ acre for 'Sweet Advantage' (Table 4). The total yield for 'SRO 1001 ' was significantly greater than 'XON-202Y', which had a total yield of $34,500 \mathrm{lb} /$ acre. 'SRO 1001' also had the greatest yield of jumbos at 40,685 $\mathrm{lb} / \mathrm{acre}$, which was significantly greater than 'EX 19013', which had a yield of jumbos of $26,056 \mathrm{lb} / \mathrm{acre}$. The greatest yield of mediums was with 'Sweet Advantage' at 8,915 lb/acre, which differed significantly from ' $2045 \mathrm{Y}$ ', which had a medium sized onion yield of $6,215 \mathrm{lb} /$ acre.

Total yield is a good indicator of genetic potential for yield for a particular variety since all entries are planted and grown the same way, but this does not always translate into a suitable variety for southeastern Georgia. Typically, growers command the best prices for jumbos, so maximizing yield in this size class is important. Later-harvested varieties tend to have greater total yields, which generally translate into greater yields of jumbos, but late season varieties can have more disease problems.
High yields of mediums usually correlate with lower yields overall and lower jumbo yields. This makes sense since a well-adapted variety that produces a high percentage of jumbos would produce fewer mediums as a consequence.

Jumbo yields in both 2002 and 2003 had relatively high cvs, which resulted in the 2002 harvest with 25 of the 31 varieties not being significantly different from the greatest yielding variety. In the 2003 , jumbo yield of 'SRO 1001' was so great that it was significantly more than all other varieties and resulted in a relatively high $\mathrm{CV}$. Because of these anomalies, no varieties were among the top performers for jumbos more than 2 years.

Those varieties with the greatest jumbo yields for 2 out of the 4 years of trials included 'Century', 'Georgia 
Table 2. Short-day onion varieties, their source, date of harvest, total yield at harvest, and cured, graded jumbo and medium yields for the 2000-01 season.

\begin{tabular}{|c|c|c|c|c|c|}
\hline Variety $^{y}$ & Seed source ${ }^{\mathrm{x}}$ & Harvest date & $\begin{array}{l}\text { Total yield } \\
(\text { lb/acre })^{\mathrm{w}}\end{array}$ & $\begin{array}{l}\text { Jumbo }^{z} \\
(\text { lb/acre })^{w}\end{array}$ & $\begin{array}{l}\text { Medium }^{\mathrm{z}} \\
{\text { (lb/acre })^{\mathrm{w}}}\end{array}$ \\
\hline Century (EX 075 92000) & Seminis (Asgrow) & 10 May & 45,491 & 38,754 & 2,076 \\
\hline SBO 133 & Nunhems (Sunseeds) & 26 Apr. & 44,642 & 31,625 & 6,019 \\
\hline ASG 6846 & Seminis (Asgrow) & 10 May & 42,500 & 35,211 & 2,483 \\
\hline Mr. Buck (DPS 1033) & D. Palmer Seed & 10 May & 42,377 & 35,792 & 2,265 \\
\hline Savannah Sweet & Seminis (Petoseed) & 3 May & 40,061 & 35,022 & 2,541 \\
\hline Cyclops (XP 6995) & Seminis (Asgrow) & 3 May & 39,560 & 29,577 & 3,049 \\
\hline Liberty & Bejo Seed & 10 May & 39,523 & 30,216 & 2,251 \\
\hline Sweet Success & Nunhems (Sunseeds) & 3 May & 38,928 & 32,394 & 3,790 \\
\hline Ohoopee Sweet (DPS 1024) & D. Palmer Seed & 10 May & 37,338 & 26,368 & 3,949 \\
\hline Granex 1035 & Seedway & 3 May & 34,432 & 25,478 & 5,072 \\
\hline Granex 33 & Seminis (Asgrow) & 3 May & 34,020 & 24,829 & 4,138 \\
\hline WI-609 & Wannamaker & 19 Apr. & 33,607 & 25,120 & 3,761 \\
\hline Nirvana (1027) & Sunseeds & 26 Apr. & 32,322 & 24,916 & 4,378 \\
\hline Southern Honey & D. Palmer Seed & 3 May & 32,176 & 24,742 & 4,545 \\
\hline $2025 \mathrm{~F}_{1}$ Yellow Granex & K\&B Development & 3 May & 32,060 & 24,568 & 4,719 \\
\hline WI-3115 & Wannamaker & 19 Apr. & 30,419 & 24,510 & 5,815 \\
\hline Georgia Boy (DPS 1032) & D. Palmer Seed & 26 Apr. & 29,977 & 19,653 & 6,418 \\
\hline PS 7092 & Seminis (Petoseed) & 26 Apr. & 27,740 & 18,121 & 6,730 \\
\hline King Midas (RCS 1919) & Nunhems (Sunseeds) & 26 Apr. & 26,717 & 17,961 & 6,585 \\
\hline Southern Belle & D. Palmer Seed & 19 Apr. & 23,384 & 7,521 & 11,681 \\
\hline
\end{tabular}

${ }^{2}$ Name in parentheses is original seed company designation.

yame in parentheses was original seed company that was either acquired or merged with parent company: Seminis = Seminis Vegetable Seeds, Oxnard, Calif.; Nunhems = Nunhems USA, Parma, Idaho; D. Palmer Seed = D. Palmer Seed Co., Yuma, Ariz.; Wannamaker = Wannamaker International, St. Matthews, S.C.; Shamrock = Shamrock Seed Co., Salinas, Calif.; Bejo Seed = Bejo Seeds, Oceano, Calif.; Samen Mauser = Samen Mauser America, El Centro, Calif.; Seedway = Seedway, Elizabethtown, Pa.; K\&B Development $=$ K\&B Development, LaQuinta, Calif.

${ }^{x} \mathrm{llb} / \mathrm{acre}=1.1209 \mathrm{~kg} \cdot \mathrm{ha}^{-1}$

wJumbo $=\geq 3$ inches $(7.6 \mathrm{~cm})$; medium $=\geq 2$ and $<3$ inches $(5.1$ and $7.6 \mathrm{~cm})$.

'Fisher's protected least significant difference with Bonferroni adjustment to make five comparisons.

Boy', 'EX 19013, 'Mr. Buck, 'Sapelo Sweet, 'Savannah Sweet, 'Sweet Vidalia', and 'WI-609'.

Previous work has shown that onions will continue to increase in size the longer they are left in the field, resulting in greater total yield (Boyhan et al., 2004). The disadvantage for delaying harvest, however, can be an increased chance of bacterial disease infection (Burkholderia spp.). During the 1999-2000 trial there was an overall decline in both total yields and jumbos with later-harvested varieties. This year was particularly bad for bacterial diseases. During the 2002 harvest there was a slightly different manifestation of the same phenomenon where total yields were greater for varieties harvested later, but jumbo yields declined. We had been routinely using forced air heat curing with all the varieties and this increased the rate of bacterial infection, which resulted in more culls during subsequent grading. During the 2003 harvest we were more cognizant of this problem and consequently stopped using the heat curing for later harvests. This resulted in total yields and jumbo yields trending higher with later-harvested varieties.

Bolting or seedstem formation can be problematic in some years. Although there is a varietal or genetic component to seedstem formation, environmental conditions play an important role. In 2000 , the average number of seedstems per 50 - $\mathrm{ft}$ plot ranged from 0 for 'Sweet Advantage' and ' $1015 \mathrm{Y}$ ' to 37 for ' $\mathrm{Mr}$.
Buck' (Table 5). 'Mr. Buck' and 'SSC $6372 \mathrm{~F}_{1}$ ' both had significantly more seedstems than other varieties in the trial in the 1999-2000 season. By contrast, in 2001 seedstems ranged from none to 16 among the varieties evaluated, with 'Pegasus' and 'Liberty' having significantly more seedstems than the other varieties with 16 and 15 , respectively (Table 6). There were seven entries that had no seedstems at all, which included 'WI-3115', 'Sweet Vidalia', 'Nirvana', 'ASG 6846', '2025 $F_{1}$ Yellow Granex', 'Savannah Sweet', and 'King Midas'. The following year's (2002) evaluation was unusual with only two seedstems noted in a single plot of 'XON-202Y'. Finally, in 2003 the average number of seedstems per 35 -ft plot ranged from 0 to 27 , which 
Table 3. Short-day onion varieties, their source, date of harvest, total yield at harvest, and cured, graded jumbo, and medium yields for the 2001-02 season.

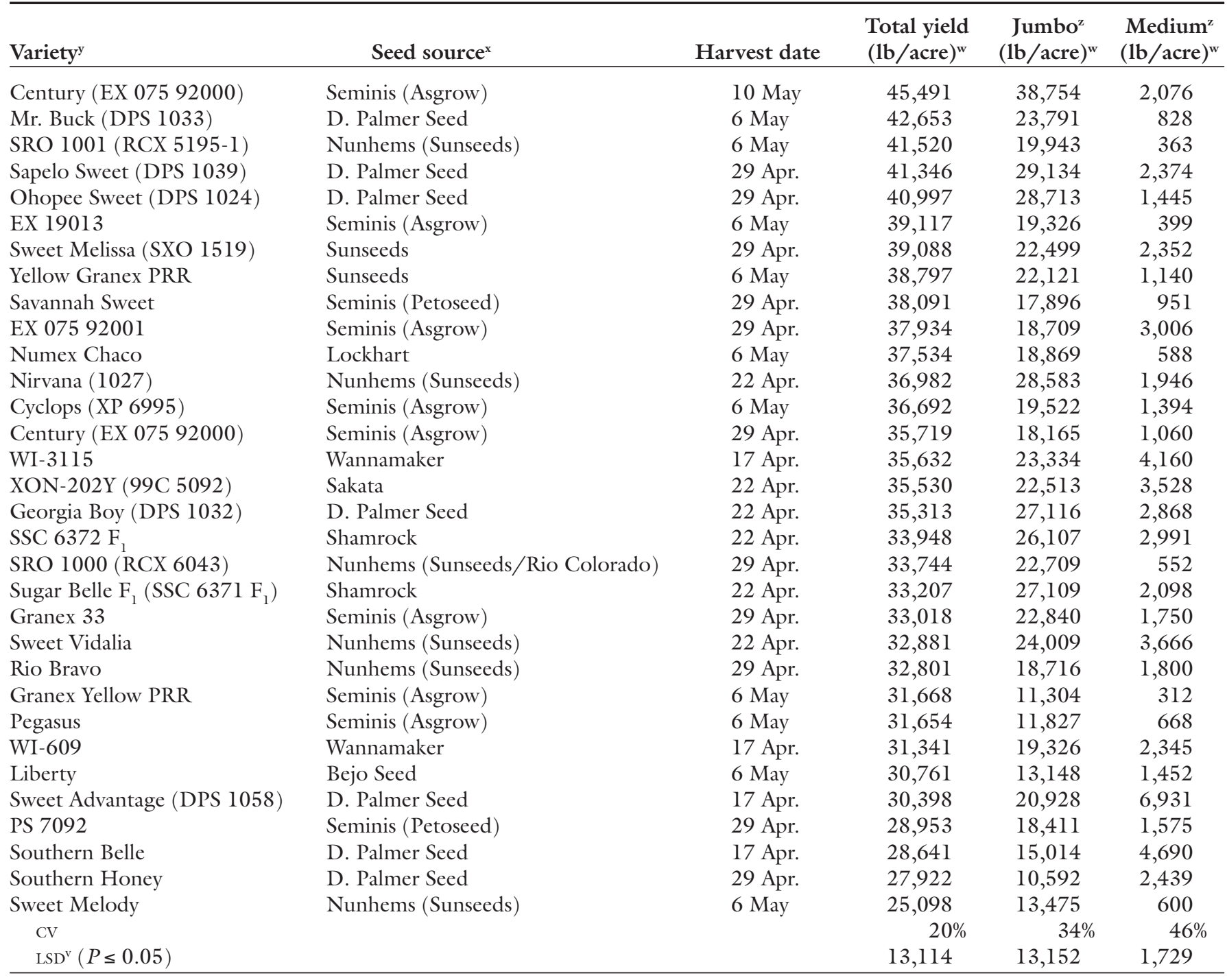

${ }^{2}$ Name in parentheses is original seed company designation.

y Name in parentheses was original seed company that was either acquired or merged with parent company: Seminis = Seminis Vegetable Seeds, Oxnard, Calif.; Nunhems = Nunhems USA, Parma, Idaho; D. Palmer Seed = D. Palmer Seed Co., Yuma, Ariz.; Wannamaker = Wannamaker International, St. Matthews, S.C.; Shamrock = Shamrock Seed Co., Salinas, Calif.; Bejo Seed = Bejo Seeds, Oceano, Calif.; Lockhart = Lockhart Seeds, Stockton, Calif.; Sakata = Sakata Seed America, Morgan Hill, Calif.

${ }^{\mathrm{x}} \mathrm{l} \mathrm{lb} / \mathrm{acre}=1.1209 \mathrm{~kg} \cdot \mathrm{ha}^{-1}$.

wumbo $=\geq 3$ inches $(7.6 \mathrm{~cm})$; medium $=\geq 2$ and $<3$ inches $(5.1$ and $7.6 \mathrm{~cm})$.

"Fisher's protected least significant difference with Bonferroni adjustment to make five comparisons.

is an equivalent range of 0 to 38 seedstems per 50 - $\mathrm{ft}$ plot. When adjusted to a 50 -ft plot, only two entries had an average of no seedstems, 'SSC 33076' and 'XON-202Y' in 2003. 'Cyclops' had the greatest number of seedstems with 27, which was significantly greater than '2012Y', which had 25 (Table 8). The largest break in adjacent seedstem means occurred between 'Yellow Granex EM $90 \mathrm{~F}_{1}$ ' and 'XON-203Y', which had 22 and 11 seedstems per plot, respectively.

As noted, earlier environmental conditions, particularly temperature, play an important role in seedstem formation. Brewster (1994) discusses at length the factors that contribute to seedstems in onions, indicating that both plant mass and temperature are important, with a minimum of 10 leaves and temperatures from 46 to 54 ${ }^{\circ} \mathrm{F}$ required for seedstem formation in overwintering onions. The amount of time required at these temperatures, however, is variety dependent. Calculating degree-day hours for temperatures between $46^{\circ} \mathrm{F}$ and $54^{\circ} \mathrm{F}$ from l Feb. to the date seedstems were counted for each year of these trials resulted in 396, 403, 274, and 288 h for 2000, 2001, 2002, and 2003, respectively. In 2002 with essentially no seedstems counted, the degree-day hours were low compared to 2000 and 2001, which had significant numbers of seedstems among some varieties. This contrasts with 2003 , which also had significant numbers of seedstems among some varieties with relatively few degree-day hours. This may indicate the importance of another significant factor, the plant size when low temperatures occur.

In 2001 and 2002, none of the varieties exceeded $5 \%$ seedstems, but in 2000 and 2003 there were six and four varieties, respectively, that did. Only one variety, 'Mr. Buck', exceeded 5\% seedstems in both 2000 and 2003.

Doubles are a physiological dis- 
Table 4. Short-day onion varieties, their source, date of harvest, total yield at harvest, and cured, graded jumbo and medium yields for the $2002-03$ season.

\begin{tabular}{|c|c|c|c|c|c|}
\hline Variety $^{\mathrm{y}}$ & Seed source ${ }^{\mathrm{x}}$ & Harvest date & $\begin{array}{l}\text { Total yield } \\
(\text { lb/acre })^{w}\end{array}$ & $\begin{array}{c}\text { Jumbo }^{z} \\
(\text { lb/acre })^{w}\end{array}$ & $\begin{array}{l}\text { Medium }^{\mathrm{z}} \\
{\text { (lb/acre })^{\mathrm{w}}}^{\text {lb }}\end{array}$ \\
\hline SRO 1001 (RCX 5195-1) & Nunhems (Sunseed) & 12 May & 45,564 & 40,685 & 472 \\
\hline XON-202Y (99C 5092) & Sakata & 12 May & 34,500 & 24,147 & 697 \\
\hline Sugar Belle $\mathrm{F}_{1}\left(\right.$ SSC $\left.6371 \mathrm{~F}_{1}\right)$ & Shamrock & 21 Apr. & 32,692 & 25,729 & 4,487 \\
\hline Ohoopee Sweet (DPS 1024) & D. Palmer Seed & 30 Apr. & 32,176 & 20,996 & 2,657 \\
\hline Mr. Buck (DPS 1033) & D. Palmer Seed & 5 May & 30,361 & 22,245 & 4,734 \\
\hline Georgia Boy (DPS 1032) & D. Palmer Seed & 5 May & 29,969 & 15,653 & 2,889 \\
\hline XON-203Y (01ZG 5034) & Sakata & 21 Apr. & 28,474 & 20,459 & 3,819 \\
\hline Sapelo Sweet (DPS 1039) & D. Palmer Seed & 30 Apr. & 28,212 & 19,660 & 4,516 \\
\hline Savannah Sweet & Seminis & 5 May & 28,053 & 19,413 & 2,977 \\
\hline $2045 \mathrm{Y}$ & K\&B Development & 30 Apr. & 26,746 & 15,972 & 6,215 \\
\hline Cyclops (XP 6995) & Seminis & 12 May & 26,659 & 17,504 & 966 \\
\hline WI-3115 & Wannamaker Seed & 14 Apr. & 26,129 & 17,613 & 5,445 \\
\hline Pegasus & Seminis & 12 May & 25,715 & 18,273 & 1,285 \\
\hline $2012 Y$ & K\&B Development & 5 May & 25,541 & 15,333 & 1,873 \\
\hline WI-609 & Wannamaker & 14 Apr. & 25,054 & 17,090 & 4,646 \\
\hline Sweet Vidalia & Nunhems (Sunseed) & 30 Apr. & 24,481 & 16,262 & 3,688 \\
\hline SRO 1000 (RCX 6043) & Nunhems (Sunseed) & 5 May & 24,198 & 10,759 & 1,713 \\
\hline $606 \mathrm{DY}$ & Shaddy & 7 Apr. & 21,874 & 7,434 & 5,852 \\
\hline SSC $6372 \mathrm{~F}_{1}$ & Shamrock & 21 Apr. & 20,742 & 12,937 & 5,474 \\
\hline SSC $33076^{1}$ & Shamrock & 7 Apr. & 20,517 & 6,694 & 8,407 \\
\hline
\end{tabular}

${ }^{2}$ Name in parentheses is original seed company designation.

yame in parentheses was original seed company that was either acquired or merged with parent company: Seminis = Seminis Vegetable Seeds, Oxnard, Calif.; Nunhems = Nunhems USA, Parma, Idaho; D. Palmer Seed = D. Palmer Seed Co.,Yuma, Ariz.; Wannamaker = Wannamaker International, St. Matthews, S.C.; Shamrock = Shamrock Seed Co., Salinas, Calif.; Sakata = Sakata Seed America, Morgan Hill, Calif.; K\&B Development $=$ K\&B Development, LaQuinta, Calif.; Emerald Seeds = Emerald Professional Vegetable Seeds Co., El Centro, Calif.; Shaddy = Shad Dasher Farm, Reidsville, Ga.

${ }^{x} 1 \mathrm{lb} /$ acre $=1.1209 \mathrm{~kg} \cdot \mathrm{ha}^{-1}$.

wJumbo $=\geq 3$ inches $(7.6 \mathrm{~cm})$; medium $=\geq 2$ and $<3$ inches $(5.1$ and $7.6 \mathrm{~cm})$.

"Fisher's protected least significant difference with Bonferroni adjustment to make five comparisons.

order where a single plant forms more than one bulb. There are a number of factors that have been cited to increase its occurrence, such as age of seedlings at transplanting, number of days to harvest, and plant density (Bhonde et al., 2001; El-Rehim, 1997). It has also been suggested that seeding and transplanting dates can be adjusted, depending on the variety, to minimize bulb doubling (D. Palmer, personal communication). Clearly, there is a varietal component to the phenomenon. In 2000, the number of doubles ranged from 0 per plot for 'Centaur' to 70 per plot for 'Georgia Boy', while the following year the range of doubles was between 0 per plot for 'Pegasus' and 99 per plot for 'SBO 133' (Tables 5 and 6). In the 1999-2000 season, 'Georgia Boy' with the highest number of doubles at 70 per plot had significantly more than the next highest, 'SSC $6436 \mathrm{~F}_{1}$ ', which had 57 per plot. 'SSC $6436 \mathrm{~F}_{1}$ ' had significantly more than the next highest, 'Granex 1035', with 30 doubles per plot. In the 2000-2001 season, this trend continued with 'SBO 133' having significantly more doubles compared to the next highest variety, 'Southern Belle', which had 92 per plot. 'Southern Belle' also had significantly more doubles than 'Sweet Advantage' with 46 per plot.

Doubles in 2002 ranged from 1 for 'Pegasus' to 69 for 'Southern Belle' and finally in 2003 the range was from 0 to 41 with 'Savannah Sweet' having none and 'Georgia Boy' having the most number of doubles (Tables 7 and 8 ). In the 2001-02 season, 'Southern Belle' with 69 doubles had significantly more than the next highest, 'Sapelo Sweet' and 'Sweet Advantage', with 43 and 42 , respectively. 'Georgia Boy' had 41 doubles in the 2002-03 season, which was significantly more than the next highest variety, 'Sugar Belle $\mathrm{F}_{1}$ ' with 26 doubles.

Two varieties, 'Sapelo Sweet' and 'Sweet Advantage', had more than 5\% doubles in 3 years of the trials. There were four varieties that had more than $5 \%$ doubles in 2 years of the trials, 
Table 5. Short-day onion varieties, their number of seedstems (bolting), doubled bulbs, bacterial disease (center rot), pyruvate analysis, bulb height: width ratio, and percent marketable onions after $\sim 4.5$ months of controlled atmosphere [3\% oxygen, $5 \%$ carbon dioxide, $70 \%$ relative humidity, $34^{\circ} \mathrm{F}\left(1.1^{\circ} \mathrm{C}\right)$ ] storage for the $1999-2000$ season.

\begin{tabular}{|c|c|c|c|c|c|c|}
\hline Entry & $\begin{array}{l}\text { Seedstems } \\
(\text { no. per } \\
\left.50 \mathrm{ft} \text { plot }^{y}\right)\end{array}$ & $\begin{array}{c}\text { Doubles } \\
\text { (no. per } \\
\left.50 \mathrm{ft} \text { plot }^{y}\right)\end{array}$ & $\begin{array}{l}\text { Bacterial } \\
\text { disease } \\
\text { infections } \\
(\text { no. per } \\
\left.50 \mathrm{ft}^{\text {plot }}{ }^{\mathrm{y}}\right) \\
\end{array}$ & $\begin{array}{l}\text { Pyruvate } \\
\left(\mu \mathrm{mol} \cdot \mathrm{g}^{-1}\right. \\
\text { fresh wt) }\end{array}$ & $\begin{array}{c}\text { Bulb } \\
\text { ht: width } \\
\text { ratio }\end{array}$ & $\begin{array}{c}\text { Post-CA }{ }^{\mathrm{z}} \\
\text { marketable } \\
\text { onions } \\
10 \text { Oct. 2000 } \\
(\%)\end{array}$ \\
\hline Savannah Sweet & 24 & 5 & 30 & 3.4 & 0.70 & 77 \\
\hline Sweet Melissa (SXO 1519) & 13 & 14 & 24 & 4.5 & 0.70 & 59 \\
\hline Georgia Boy (DPS 1032) & 21 & 70 & 39 & 4.8 & 0.81 & 64 \\
\hline Sweet Success & 16 & 12 & 46 & 4.0 & 0.72 & 55 \\
\hline Sweet Vidalia & 5 & 6 & 16 & 4.6 & 0.74 & 61 \\
\hline WI-609 & 9 & 19 & 11 & 4.4 & 0.73 & 32 \\
\hline Cyclops (XP 6995) & 12 & 11 & 72 & 3.1 & 0.72 & 66 \\
\hline Sapelo Sweet (DPS 1039) & 5 & 22 & 28 & 4.5 & 0.73 & 66 \\
\hline Mr. Buck (DPS 1033) & 37 & 18 & 48 & 4.1 & 0.69 & 45 \\
\hline Granex 33 & 1 & 3 & 74 & 3.5 & 0.73 & 66 \\
\hline Yellow Granex Imp. (Sun $\left.F_{1}\right)$ & 29 & 2 & 29 & 4.4 & 0.61 & 62 \\
\hline Sweet Melody & 4 & 5 & 38 & 3.9 & 0.71 & 67 \\
\hline Sugar Belle $\mathrm{F}_{1}\left(\mathrm{SSC}\right.$ 6371 $\left.\mathrm{F}_{1}\right)$ & 4 & 26 & 20 & 4.9 & 0.82 & 51 \\
\hline SSC $6436 \mathrm{~F}_{1}$ & 16 & 57 & 53 & 5.1 & 0.77 & 64 \\
\hline Granex 1035 & 25 & 30 & 44 & 4.7 & 0.89 & 68 \\
\hline WI-3115 & 3 & 18 & 26 & 5.2 & 0.94 & 41 \\
\hline PS 7092 & 2 & 24 & 56 & 4.3 & 0.83 & 58 \\
\hline Sweet Advantage (DPS 1058) & 0 & 23 & 27 & 4.7 & 0.79 & 66 \\
\hline Georgia Pride $\mathrm{F}_{1}$ & 7 & 18 & 17 & 5.4 & 0.61 & 55 \\
\hline King Midas (RCS 1919) & 2 & 11 & 69 & 5.0 & 0.92 & 68 \\
\hline Sweet Sun & 2 & 6 & 64 & 2.4 & 0.98 & 39 \\
\hline SSC $6372 \mathrm{~F}_{1}$ & 35 & 13 & 33 & 5.0 & 0.75 & 73 \\
\hline Nikita & 2 & 4 & 183 & 3.7 & 0.89 & 52 \\
\hline Evita $F_{1}$ & 4 & 4 & 40 & 4.3 & 0.82 & 5 \\
\hline Pegasus & 3 & 5 & 127 & 2.5 & 0.63 & 9 \\
\hline Centaur & 2 & 0 & 122 & 3.3 & --- & --- \\
\hline $1015 \mathrm{Y}$ & 0 & 5 & 45 & 3.1 & 0.95 & 11 \\
\hline $\mathrm{CV}$ & $31 \%$ & $30 \%$ & $26 \%$ & $23 \%$ & & $25 \%$ \\
\hline $\operatorname{LSD}^{\mathrm{x}}(P \leq 0.05)$ & 2 & 4 & 11 & 0.8 & & 14 \\
\hline
\end{tabular}

${ }^{2}$ Controlled atmosphere.

v $50 \mathrm{ft}=15.2 \mathrm{~m}$.

${ }^{x}$ Fisher's protected least significant difference with Bonferroni adjustment to make five comparisons.

which included 'Georgia Boy', 'Mr. Buck', 'Southern Belle', and 'Sugar Belle $\mathrm{F}_{1}$ '.

In the 1999-2000 season the incidence of center rot was very prevalent, so counts were taken within each plot of infected plants (Table 5). The range was 11 for 'WI-609' to 183 for 'Nikita'. 'Nikita' was highly susceptible to center rot with significantly more plants infected compared to the next greatest variety, 'Pegasus', which had 127 plants infected. 'Pegasus' did not differ in center rot incidence compared to 'Centaur', which also had a relatively high count at 122 plants infected. The next greatest variety for number of infected plants was 'Granex 33' with 74. From 'Granex 33' to the 'WI-609' there were no significant differences between adjacent varieties ranked in order of center rot incidence. 'WI-609' did not differ significantly in center rot occurance compared to 'Sugar Belle F', which had 20 plants infected. In addition to center rot incidence in 2000 , stand counts were recorded in 2003 (Table 8). Plant age is known to affect susceptibility to freezing with older plants being less susceptible than younger plants (Brewster, 1990). The 2002-03 season was marked by a cooler than normal winter, which slowed plant growth resulting in stand loss. Stand counts ranged from 295 for 'Sweet Melody' to 418 for 'Sugar Belle F'. We calculated the maximum stand for a plot at 424 plants. Many of the entries had very little stand loss, along with 'Sugar Belle F', 'Ohoopee Sweet' , 'SRO 1001', '2045Y', 'WI-129', and
'Granex 33' did not differ significantly from the maximum of 424 plants per plot. Stand loss appeared to occur primarily among those varieties that had a greater percentage of smaller, less vigorous plants at transplanting. Disease was the primary cause of stand loss, which appeared to be affected by cold winter temperatures slowing plant growth resulting in losses among plants without enough reserves to recover when growth resumed.

Pyruvate analysis, is an indicator of flavor intensity or pungency in onions, and has been correlated with flavor perception using taste panels (Wall and Corgan, 1992). Pyruvate analysis became an important criterion for evaluating short-day onions in southeastern Georgia because of the perceived pungency among Japanese 
Table 6. Short-day onion varieties, their number of seedstems (bolting), doubled bulbs, pyruvate analysis, and percent marketable onions after $\sim 4.5$ months of controlled atmosphere [ $3 \%$ oxygen, $5 \%$ carbon dioxide, $70 \%$ relative humidity, $\left.34^{\circ} \mathrm{F}\left(1.1^{\circ} \mathrm{C}\right)\right]$ storage for the $2000-01$ season.

\begin{tabular}{|c|c|c|c|c|}
\hline Variety & $\begin{array}{c}\text { Seedstems } \\
(\text { no. per } \\
\left.50-\mathrm{ft} \text { plot }^{\mathrm{y}}\right)\end{array}$ & $\begin{array}{c}\text { Doubles } \\
\text { (no. per } \\
\left.50-\text { ft plot }^{\mathrm{y}}\right)\end{array}$ & $\begin{array}{l}\text { Pyruvate } \\
\left(\mu \mathrm{mol} \cdot \mathrm{g}^{-1}\right. \\
\text { fresh wt) }\end{array}$ & $\begin{array}{c}\text { Post-CA }{ }^{\mathrm{z}} \\
\text { marketable } \\
\text { onions } \\
2 \text { Oct. } 2001 \\
(\%)\end{array}$ \\
\hline Century (EX 075 92000) & 1 & 3 & 4.7 & 69 \\
\hline EX 19013 & 2 & 2 & 4.7 & 74 \\
\hline SBO 133 & 10 & 99 & 4.0 & 53 \\
\hline ASG 6846 & 0 & 2 & 5.3 & 78 \\
\hline Mr. Buck (DPS 1033) & 1 & 5 & 4.6 & 77 \\
\hline PS 7292 & 4 & 3 & 5.0 & 76 \\
\hline Pegasus & 16 & 0 & 4.9 & 64 \\
\hline Savannah Sweet & 0 & 3 & 3.4 & 88 \\
\hline Cyclops (XP 6995) & 7 & 4 & 2.8 & 84 \\
\hline Liberty & 15 & 24 & 5.0 & 71 \\
\hline Sweet Success & 10 & 23 & 3.1 & 83 \\
\hline Ohoopee Sweet (DPS 1024) & 1 & 11 & 4.7 & 86 \\
\hline Sweet Melody & 4 & 4 & 2.7 & 87 \\
\hline Sweet Vidalia & 0 & 1 & 2.8 & 84 \\
\hline Hybrid Yellow Granex 107 & 11 & 5 & 2.9 & 86 \\
\hline Sweet Melissa (SXO 1519) & 3 & 20 & 2.3 & 79 \\
\hline Granex 1035 & 1 & 21 & 3.5 & 90 \\
\hline Granex 33 & 1 & 5 & 3.6 & 84 \\
\hline WI-609 & 1 & 4 & 2.9 & 44 \\
\hline Nirvana (1027) & 0 & 1 & 4.3 & 58 \\
\hline Southern Honey & 1 & 3 & 3.7 & 88 \\
\hline $2025 \mathrm{~F}_{1}$ Yellow Granex & 0 & 2 & 4.4 & 82 \\
\hline WI-3115 & 0 & 11 & 3.4 & 43 \\
\hline Georgia Boy (DPS 1032) & 1 & 12 & 4.4 & 67 \\
\hline PS 7092 & 1 & 5 & 4.9 & 79 \\
\hline King Midas (RCS 1919) & 0 & 4 & 5.1 & 72 \\
\hline Southern Belle & 1 & 92 & 4.1 & 50 \\
\hline Sweet Advantage (DPS 1058) & 1 & 46 & 4.3 & 51 \\
\hline $\mathrm{CV}$ & $38 \%$ & $22 \%$ & $28 \%$ & $13 \%$ \\
\hline $\operatorname{LSD}^{\mathrm{x}}(P \leq 0.05)$ & 1 & 1 & 1.5 & 6 \\
\hline
\end{tabular}

${ }^{\mathrm{z} C o n t r o l l e d ~ a t m o s p h e r e . ~}$

y $50 \mathrm{ft}=15.2 \mathrm{~m}$.

'Fisher's protected least significant difference with Bonferroni adjustment to make five comparisons

overwintering onions that were introduced to the Vidalia onion industry several years ago. Japanese overwintering varieties had two important characteristics growers were interested in, improved foliar disease resistance and earliness. These onions were at least 2 weeks earlier than any previous onions grown in the Vidalia district. Earliness was desirable because traditionally this has resulted in higher prices. However many growers and others involved in Vidalia onion production were concerned that these early onions with their perceived increased pungency would hurt the industry overall.

In 2001, the Georgia Department of Agriculture adopted rules that required the Director of the
Georgia Agricultural Experiment Station recommend varieties for inclusion and exclusion from an official list of approved varieties. These recommendations were based primarily on pungency as measured by pyruvate analysis and taste panel evaluation with a professional taste panel (data not shown). Initially our standard variety for evaluating pungency and taste was 'Sweet Vidalia,' which was changed to 'Savannah Sweet' in 2003.

In 2000, prior to adoption of these rules, pyruvate ranged from 2.4 to 5.4 $\mu \mathrm{mol} \cdot \mathrm{g}^{-1} \mathrm{FW}$ with 'Sweet Sun' having the lowest pyruvate and 'Georgia Pride $\mathrm{F}_{1}$ ' having the highest pyruvate. 'Sweet Sun' generated significantly less pyruvate than 'Centaur,' which had
$3.3 \mu \mathrm{mol} \cdot \mathrm{g}^{-1} \mathrm{FW}$ pyruvate. Among the varieties that were considered Japanese overwintering onions were 'WI-609,' 'WI-31 15, 'Sugar Belle F ${ }_{1}$, 'SSC 6372 $\mathrm{F}_{1}$,' 'SSC $6436 \mathrm{~F}_{1}$ ', and 'Georgia Pride $\mathrm{F}_{1}$,' which had pyruvate values of 4.4 , $5.2,4.9,5.0,5.1$, and $5.4 \mu \mathrm{mol} \cdot \mathrm{g}^{-1} \mathrm{FW}$, respectively (Table 5 ). Although these pyruvate values were in the upper half of pyruvates in 2000 , they were not significantly worse than many onion varieties considered acceptable.

The pyruvate values in 2001 ranged from $2.3 \mu \mathrm{mol} \cdot \mathrm{g}^{-1} \mathrm{FW}$ for 'Sweet Melissa' to $5.3 \mu \mathrm{mol} \cdot \mathrm{g}^{-1} \mathrm{FW}$ for 'ASG 6846' (Table 6). 'Sweet Melissa' produced significantly less pyruvate than 'SBO 133' with $4.0 \mu \mathrm{mol} \cdot \mathrm{g}^{-1}$ FW. The two Japanese overwintering entries in 2001, 'WI-609' and 'WI3115 ,' had pyruvates of 2.9 and 3.4 $\mu \mathrm{mol} \cdot \mathrm{g}^{-1} \mathrm{FW}$, respectively. In 2002 , the pyruvate ranged from 1.1 to 3.5 umol. $\mathrm{g}^{-1} \mathrm{FW}$ with 'RCX 6043' having the lowest value and 'Southern Belle' having the highest (Table 7). Among the Japanese overwintering varieties the range was 1.2 to $2.3 \mu \mathrm{mol} \cdot \mathrm{g}^{-1}$ FW pyruvate, which would not be considered overly pungent. Finally, in 2003 pyruvate ranged from 2.8 to 5.0 $\mu \mathrm{mol} \cdot \mathrm{g}^{-1} \mathrm{FW}$ with four of the five lowest values among the Japanese overwintering varieties (Table 8). These included 'SSC 33076,' '72766 DY,' '606 DY,' and 'WI-129.'

The perceived pungency of these Japanese overwintering varieties may have more to do with how they are handled. These varieties are strongly daylength responsive with early and uniform foliar lodging. Onions will continue to size and presumably be milder due to increased water uptake if left in the ground even after the tops have fallen (Boyhan et al., 2004). Since growers are interested in garnering early market premiums they dig these onions when the tops begin to break over, but before they have completely matured. This may be one of the reasons these onions have a reputation for pungency. It has also been suggested that there may be one or more other compounds unique to these onions that impart an objectionable taste that has not been identified. Such a bitter after taste has been reported in other varieties such as 'Zittauer Gelbe' and 'H-49' (Jirik and Pospisilova, 1981).

Vidalia onions grown in southeastern Georgia are required to be yellow Granex type short-day onions. 
Table 7. Short-day onion varieties, their number of doubled bulbs, pyruvate analysis, number of visible centers in cut bulb, bulb height/width ratio, percent marketable onions after 4.5 months of controlled atmosphere [ $3 \%$ oxygen, $5 \%$ carbon dioxide, $70 \%$ relative humidty, $34^{\circ} \mathrm{F}\left(1.1^{\circ} \mathrm{C}\right)$ ] storage, and percent marketable onions $14 \mathrm{~d}$ after removal from controlled atmosphere at $\sim 75^{\circ} \mathrm{F}$ for the $2001-02$ season.

\begin{tabular}{|c|c|c|c|c|c|c|}
\hline Variety $^{y}$ & $\begin{array}{c}\text { Doubles } \\
\text { no. per } \\
\left(\text { 50-ft plot }{ }^{y}\right) \\
\end{array}$ & $\begin{array}{l}\text { Pyruvate } \\
\left(\mu \mathrm{mol} \cdot \mathrm{g}^{-1}\right. \\
\text { fresh wt })\end{array}$ & $\begin{array}{c}\text { Bulb } \\
\text { centers } \\
\text { (no.) }\end{array}$ & $\begin{array}{c}\text { Ht : width } \\
\text { ratio }\end{array}$ & $\begin{array}{c}\text { Post-CA }{ }^{\mathrm{z}} \\
\text { marketable } \\
\text { onions } \\
7 \text { Oct. } 2002 \\
(\%) \\
\end{array}$ & $\begin{array}{c}\text { Post-CA }{ }^{z} \\
\text { marketable } \\
\text { onions } \\
21 \text { Oct } 2002 \\
(\%) \\
\end{array}$ \\
\hline Mr. Buck (DPS 1033) & 8 & 2.1 & 2.6 & 0.74 & 76 & 52 \\
\hline SRO 1001 (RCX 5195-1) & 4 & 1.5 & 1.0 & 0.71 & 79 & 66 \\
\hline Sapelo Sweet (DPS 1039) & 43 & 2.3 & 1.7 & 0.69 & 88 & 83 \\
\hline Ohoopee Sweet (DPS 1024) & 5 & 1.9 & 1.9 & 0.70 & 89 & 82 \\
\hline EX 19013 & 1 & 1.9 & 1.3 & 0.79 & 86 & 69 \\
\hline Sweet Melissa (SXO 1519) & 8 & 1.4 & 1.5 & 0.69 & 88 & 77 \\
\hline Yellow Granex PRR Sunseed & 5 & 1.8 & 2.4 & 0.72 & 80 & 62 \\
\hline Savannah Sweet & 6 & 1.3 & 1.6 & 0.78 & 80 & 52 \\
\hline EX 07592001 & 13 & 2.2 & 1.2 & 0.75 & 83 & 72 \\
\hline Numex Chaco & 6 & 2.8 & 1.2 & 1.04 & 89 & 79 \\
\hline Nirvana (1027) & 8 & 1.7 & 1.3 & 0.73 & 85 & 75 \\
\hline Cyclops (XP 6995) & 14 & 2.1 & 1.4 & 0.76 & 76 & 49 \\
\hline Century (EX 075 92000) & 3 & 1.7 & 1.7 & 0.73 & 83 & 72 \\
\hline WI-3115 & 13 & 2.3 & 1.8 & 0.90 & 77 & 62 \\
\hline XON-202Y (99C 5092) & 3 & 1.6 & 1.4 & 0.77 & 81 & 73 \\
\hline Georgia Boy (DPS 1032) & 6 & 1.9 & 1.4 & 0.94 & 90 & 83 \\
\hline SSC $6372 \mathrm{~F}_{1}$ & 5 & 1.2 & 1.2 & 0.68 & 87 & 82 \\
\hline RCX 6043 & 1 & 1.1 & 1.2 & 0.65 & 88 & 79 \\
\hline Sugar Belle $\mathrm{F}_{1}\left(\right.$ SSC $\left.6371 \mathrm{~F}_{1}\right)$ & 5 & 1.7 & 1.2 & 0.69 & 84 & 77 \\
\hline Granex 33 & 7 & 1.8 & 1.6 & 0.79 & 81 & 71 \\
\hline Sweet Vidalia & 7 & 1.3 & 1.2 & 0.69 & 84 & 74 \\
\hline Rio Bravo & 8 & 1.8 & 1.9 & 0.72 & 81 & 65 \\
\hline Granex Yellow, PRR Asgrow & 6 & 2.1 & 1.5 & 0.69 & 81 & 66 \\
\hline Pegasus & 1 & 1.8 & 1.5 & 0.72 & 81 & 69 \\
\hline WI-609 & 7 & 1.7 & 1.1 & 0.67 & 83 & 72 \\
\hline Liberty & 2 & 2.7 & 1.5 & 1.11 & 85 & 69 \\
\hline Sweet Advantage (DPS 1058) & 42 & 2.8 & 1.5 & 0.79 & 85 & 79 \\
\hline PS 7092 & 9 & 2.0 & 1.5 & 0.72 & 87 & 76 \\
\hline Southern Belle & 69 & 3.5 & 1.7 & 0.76 & 79 & 71 \\
\hline Southern Honey & 8 & 2.5 & 1.6 & 0.71 & 82 & 69 \\
\hline Sweet Melody & 6 & & 2.0 & 0.78 & 61 & 32 \\
\hline $\mathrm{CV}$ & $43 \%$ & $25 \%$ & $10 \%$ & & $7 \%$ & $11 \%$ \\
\hline $\operatorname{LSD}^{x}(P \leq 0.05)$ & 5.0 & 0.9 & 0.1 & & 2 & 4 \\
\hline
\end{tabular}

${ }^{\mathrm{z}}$ Controlled atmosphere.

${ }^{\mathrm{y}} 50 \mathrm{ft}=15.2 \mathrm{~m}$.

Granex type onions are slightly flattened onions with a height to width ratio well below 1 . It is known however that round onions will generally have higher yields per area and will yield more onion rings for processing. For these reasons, onions with a height to width ratio up to 1 are allowed as Vidalia onions. In the 1999-2000 season, height/width ratios ranged from 0.61 for 'Georgia Pride F' $F_{1}$ and 'Yellow Granex Improved' to 0.98 for 'Sweet Sun' (Table 5). In the 2001-2002 season, height: width ratios ranged from 0.65 for 'RCX 6043 ' to 1.11 for 'Liberty' (Table 7). Varieties with height/width ratios above 1 (often referred to as 'torpedoes') are not allowed to be grown as Vidalia onions.

The percent marketable onions post-CA ranged from $5 \%$ for 'Evita $\mathrm{F}_{1}$ ' to $77 \%$ for 'Savannah Sweet' in 2000 (Table 5). Over $98 \%$ of the onions culled after removal from CA storage was due to botrytis neck rot (Botrytis aclada). Percent marketable onions after CA was significantly lower for early harvested varieties (6 Apr. 2000) compared to 'Savannah Sweet.' The highest percent marketable onion after CA of these early varieties was 'Georgia Pride $\mathrm{F}_{1}$ ' with $55 \%$. Other early variet- ies included 'WI-609' with 32\% and 'WI-3115' with $41 \%$ post-CA marketable onions. Late varieties harvested on 11 May 2000 also exhibited low percent marketable onions post-CA. Onions harvested on 11 May 2000 had post-CA marketable onions that ranged from $5 \%$ to $45 \%$ and included 'Evita $\mathrm{F}_{1}$,' 'Pegasus,' '1015Y,' and 'Mr. Buck.'

Overall, the percent marketable onions post-CA in 2001 was very good with two-thirds of the varieties having more than $70 \%$ marketable. The worst storing varieties in 2001 included all of the earliest harvested 
Table 8. Short-day onion varieties, their number of seedstems (bolting), doubled bulbs, number of plants per plot (stand count), pyruvate analysis, percent marketable onions after 4.5 months of controlled atmosphere [ $3 \%$ oxygen, $5 \%$ carbon dioxide, $70 \%$ relative humidity, $34^{\circ} \mathrm{F}\left(1.1^{\circ} \mathrm{C}\right)$ ] storage, and percent marketable onions $16 \mathrm{~d}$ after removal from controlled atmosphere storage at $\sim 75^{\circ} \mathrm{F}$ for the $2002-03$ season.

\begin{tabular}{|c|c|c|c|c|c|c|}
\hline Variety & $\begin{array}{l}\text { Seedstems } \\
\text { (no. per } \\
\left.\text { 35-ft plot }{ }^{y}\right)\end{array}$ & $\begin{array}{c}\text { Doubles } \\
\text { (no. per } \\
\left.\text { 35-ft plot }{ }^{y}\right)\end{array}$ & $\begin{array}{c}\text { Stand } \\
\text { count } \\
(\text { no. per } \\
\left.\text { 35-ft plot }{ }^{y}\right)\end{array}$ & $\begin{array}{l}\text { Pyruvate } \\
\left(\text { umol.g }{ }^{-1}\right. \\
\text { fresh wt) }\end{array}$ & $\begin{array}{c}\text { Post-CA }{ }^{\mathrm{z}} \\
\text { marketable } \\
\text { onions } \\
\text { 1 Oct } 2003 \\
(\%)\end{array}$ & $\begin{array}{c}\text { Post-CA }^{z} \\
\text { marketable } \\
\text { onions } \\
16 \text { Oct } 2003 \\
(\%)\end{array}$ \\
\hline SRO 1001 (RCX 5195-1) & 4 & 3 & 412 & 3.7 & 2 & 0 \\
\hline EX 19013 & 8 & 3 & 352 & 4.4 & 5 & 0 \\
\hline 99C 5092 & 0 & 2 & 401 & 4.4 & 0 & 0 \\
\hline Sugar Belle $\mathrm{F}_{1}\left(\right.$ SSC $\left.6371 \mathrm{~F}_{1}\right)$ & 1 & 26 & 418 & 4.9 & 0 & 0 \\
\hline Ohoopee Sweet (DPS 1024) & 2 & 10 & 412 & 4.7 & 15 & 7 \\
\hline WI-129 & 2 & 4 & 410 & 3.4 & 0 & 0 \\
\hline Century (EX 075 92000) & 2 & 3 & 389 & 4.8 & 9 & 2 \\
\hline Mr. Buck (DPS 1033) & 24 & 13 & 394 & 4.6 & 7 & 2 \\
\hline Georgia Boy (DPS 1032) & 8 & 41 & 403 & 4.7 & 13 & 6 \\
\hline XON-203Y (01ZG 5034) & 11 & 6 & 406 & 4.0 & 0 & 0 \\
\hline Sapelo Sweet (DPS 1039) & 2 & 20 & 383 & 3.8 & 14 & 10 \\
\hline Savannah Sweet & 1 & 0 & 401 & 4.1 & 14 & 3 \\
\hline Granex Yellow PRR & 8 & 6 & 401 & 4.5 & 1 & 0 \\
\hline Nirvana (1027) & 0 & 1 & 339 & 4.5 & 16 & 6 \\
\hline Granex 33 & 6 & 5 & 409 & 5.0 & 19 & 10 \\
\hline Yellow Granex EM $90 \mathrm{~F}_{1}$ & 22 & 3 & 405 & 4.3 & 7 & 2 \\
\hline $2045 Y$ & 1 & 14 & 410 & 4.8 & 7 & 2 \\
\hline Cyclops (XP 6995) & 27 & 6 & 394 & 4.6 & 1 & 0 \\
\hline WI-3115 & 2 & 4 & 400 & 3.9 & 0 & 0 \\
\hline Pegasus & 7 & 9 & 384 & 5.0 & 0 & 0 \\
\hline $2012 \mathrm{Y}$ & 25 & 1 & 405 & 5.0 & 8 & 2 \\
\hline WI-609 & 3 & 5 & 408 & 3.7 & 0 & 0 \\
\hline Sweet Vidalia & 3 & 4 & 396 & 4.4 & 8 & 2 \\
\hline SRO 1000 (RCX 6043) & 1 & 1 & 346 & 3.9 & 23 & 9 \\
\hline $606 \mathrm{DY}$ & 1 & 1 & 401 & 3.2 & 0 & 0 \\
\hline SSC $6372 \mathrm{~F}_{1}$ & 9 & 5 & 383 & 4.7 & 0 & 0 \\
\hline SSC $33076^{1}$ & 0 & 1 & 397 & 2.8 & 0 & 0 \\
\hline Sweet Melody & 2 & 4 & 295 & 4.4 & 14 & 5 \\
\hline $72766 \mathrm{DY}$ & 1 & 3 & 380 & 3.0 & 0 & 0 \\
\hline Sweet Advantage (DPS 1058) & 0 & 12 & 389 & 4.6 & 0 & 0 \\
\hline $\mathrm{CV}$ & $36 \%$ & $37 \%$ & $39 \%$ & $14 \%$ & $56 \%$ & $84 \%$ \\
\hline $\operatorname{LSD}^{x}(P \leq 0.05)$ & 2 & 2.4 & 15 & 1.2 & 4 & 3 \\
\hline
\end{tabular}

${ }^{2}$ Controlled atmosphere.

y $35 \mathrm{ft} .=10.7 \mathrm{~m}$.

${ }^{x}$ Fisher's protected least significant difference with Bonferroni adjustment to make five comparisons.

varieties, which included 'WI-3115,' 'WI-609,' 'Southern Belle,' and 'Sweet Advantage' with $43 \%, 44 \%, 50 \%$, and $51 \%$ post-CA marketable onions, respectively (Table 6). The late harvested (11 May 2001) varieties did not perform as poorly as in 2000 with 6 of 8 varieties with greater than $70 \%$ marketable onions post-CA.

In 2002, the percent marketable onions post-CA ranged from $61 \%$ to $90 \%$ with 30 of the 31 varieties having more than $75 \%$ marketable onions (Table 7). Seventy-seven percent of the culls from storage were due to botrytis neck rot. Varieties were also evaluated $14 \mathrm{~d}$ after removal from storage and percent marketable yield ranged from 32\% for 'Sweet Melody' to $83 \%$ for 'Georgia Boy.' There was an average $16 \%$ loss of marketable onions for all varieties over the $14 \mathrm{~d}$ post-CA. Those varieties that had lower percent marketable yield post-CA lost more onions (up to $47 \%$ for 'Sweet Melody') than those that had higher percent marketable onions right out of storage. For example, 'SSC $6372 \mathrm{~F}_{1}$,' 'Sapelo Sweet,' and 'Georgia Boy' lost $5 \%, 6 \%$, and $8 \%$, respectively in the 14 d post-CA.

The CA storage results were the poorest in 2003. The highest percent marketable onions post-CA was $23 \%$ for 'SRO 1000' (Table 8). In addition, of the 31 varieties in the trial, 12 had no marketable onions after removal from CA storage. Fourteen days after removal from storage over half of the varieties had no marketable onions. Finally, almost $100 \%$ of those onions culled from storage in 2003 were due to botrytis neck rot.

CA storage has been an important technology adopted by the Georgia onion industry and was instrumental in acres increasing from 4800 acres in 1989 to 14,000 acres in 2003 (USDA, 1995b; USDA, 2004). Botrytis neck rot is known to be acquired in the field prior to CA storage and can grow un- 
der CA conditions, but is incapable of sporulating (Purvis and Brock, 2003). Further, it is known that botrytis neck rot can be destroyed with high temperature $\left(90\right.$ to $100^{\circ} \mathrm{F}$ ) curing for 14 d (Gunkel et al., 1971). It is still not known why the percent marketable onions after CA storage would fluctuate so radically from 1 year to the next. It is difficult if not impossible to identify the pathogen once it has gained entry to a bulb and extended heat curing is impossible because of the susceptibility to other pathogens as well as the darkening of the outer scales.

These trials have supplied useful information to the Vidalia onion industry particularly the evaluation of new varieties for a number of different characteristics. The initial rationale for the trials over the perceived pungency of early onions and an attempt to remove them from cultivation has not been successful. The objectionable flavor many have perceived has not correlated well with pyruvate analyses and both cultural practices and an as yet unidentified compound have not been ruled out.

In terms of other attributes measured, the trials have been successful at pinpointing the best adapted varieties for southeastern Georgia. The most important yield component is in the jumbo size class and those varieties that consistently produced the highest yields in this class were among the early and mid-season maturing onions. Many late-season varieties have high total yield, but jumbo yields are lacking. This is primarily due to late season warm weather bacterial diseases.

Environment may be the major factor affecting seedstems and doubles, but the varietial component is particularly evident with some entries. Varieties that are prone to these problems often exhibit greater vigor and more growth during the season. This apparent accelerated growth may contribute to both seedstems and doubles.

Early varieties had lower percent marketable onions after CA storage than later harvested onions. This may be partially explained by the way we handled the onions. Early harvested onions were held in refrigerated storage until all the onions were harvested before being placed in CA storage so that all the varieties would be in $\mathrm{CA}$ storage for the same length of time. This may have allowed endemic pathogens to spread more widely among these onions. It should be pointed out, however, that CA storage is not an important factor for early onions since they are destined for the fresh market.

Finally, not one single characteristic is important to growers when selecting varieties. Most growers will handle more than one variety, if for nothing else than to select early, midseason, and late maturing varieties. In addition, mild flavor, good shelf life, suitability for CA storage, and visual appeal are all characteristics growers consider when choosing Vidalia onion varieties.

\section{Literature cited}

Bhonde, S.R., A.B. Chougule, and N.B. Singh. 2001. Studies on the effect of age of seedlings and date of harvesting on yield and quality of onion during late kharif season. Nwsl. Natl. Hort. Res. Dev. Foundation $21: 27-30$

Boyhan, G.E., A.C. Purvis, W.C. Hurst, R.L. Torrance, and J.T. Paulk. 2004. Harvest date effect on yield and controlledatmosphere storability of short-day onions. HortScience 39:1623-1629.

Boyhan, G.E., A.C. Purvis, W.M. Randle, R.L. Torrance, D.E. Curry, R.T. Boland, C.R. Hill, M.J. Cook, M.D. Graham, and J.T. Paulk, 2001. Vidalia and Grano onion variety trials 1999-2000, p. 7-11 In: B.W. Maw (ed.). 2000 Georgia onion research-Extension report. Coop. Res. Ext. Publ. No. 3-2001.

Boyhan, G.E. and R.L. Torrance. 2002. Vidalia onions-Sweet onion production in southeastern Georgia. HortTechnology 12:196-202.

Boyhan, G.E., R.L. Torrance, D.E. Curry, P.M. Lewis, D.O. Linton, and C.R. Hill. 2002. Evaluation of transplant fertility of short-day onions in southeast Georgia. HortScience 37:651-655.

Brewster, J.L. 1990. Physiology of crop growth and bulbing, p. 53-88. In: H.D. Rabinowitch and J.L. Brewster (eds.). Onions and allied crops, vol. I: Botany, physiology, and genetics. CRC Press, Boca Raton, Fla.

Brewster, J.L. 1994. Onions and other vegetable alliums, vol. 3. CAB Intl., Wallingford, U.K.

Cramer, C.S. 2001. Comparison of open-pollinated and hybrid onion varieties for New Mexico. HortTechnology 11:119-123.

Doherty, B.A., N. Dykes, and J.C. McKissick. 2002. 2001 Georgia farm gate value report. Univ. of Georgia Agr. Rpt. AR-02-02.

El-Rehim, G.H.A.A.F.A.S.G.I.W.A.A. 1997. Effect of transplanting date and planting density on bulb yield and quality of Giza 20 onion in upper Egypt. Egyptian J. Agr. Res. 75:681-695.

Ergeshova, K. 1987. Onion varieties for Kirgizia. Nauchnye Trudy Kirgizskogo Nauchno-Proizvodstvennogo Ob"edineniya po Zemledeliyu 24:150-152.

Fuqua, M.C. and G.R. Howell. 1975. Variety and planting-date trials of spring and fall field-seeded onions in the rolling plains of Texas. Texas Agr. Expt. Sta. Prog. Rpt. No. PR-3303.

Granberry, D.M., D. Smittle, W. McLaurin, and R.L. Shewfelt. 1987. The effects of calcium sulfate on leaf and bulb tissue, sulfur content and on pungency of the "Vidalia" onion. Proc. Natl. Onion Res. Conf. 10-11 Dec. 1987. p. 27-32.

Gunkel, W.W., J.W. Lorbeer, J. Kaufman, H.A. Smith, Jr. 1971. Artificial drying-A method for control of botrytis neck rot in bulk stored onions. Cornell Univ. Ann. Prog. Rpt. 28:71-80.

Jirik, J. and J. Pospisilova. 1981. Sensory evaluation of the principal onion (Allium cepa) cultivars and new selections. Bul. Vyzkumny a Slechtitelsky Ustav Zelinarsky Olomouc 25/26:3-18.

Lallan Singh, S.P. Singh, and P.K. Mishra. 1992. Evaluation of onion varieties at Karnal. Nwsl. Assoc. Agr. Dev. Foundation 11:3-4.

Little, T.M. and F.J. Hills. 1978. Agricultural experimentation design and analysis. Wiley, New York.

Maynard, D.N. 1989. Vegetable variety trial results in Florida for 1988. Univ. of Florida Agr. Expt. Sta. Circ. S-363.

Maynard, D.N. 2002. Enhancing the scope of vegetable cultivar evaluation in Florida. HortTechnology 12:560-561.

Pagano, M. and K. Gauvreau. 2000. Principles of biostatistics. Duxbury, Pacific Grove, Calif.

Purvis, A.C. and J. Brock. 2003. Does Botrytis allii spread from infected onins to sound onions in controlled atmosphere storage? Acta Hort. 600:615-619.

Quadir, M.A., M. Hickey, A. Boulton, and M. Snudden. 2002. Mild or sweet onion evaluation of varieties in New South Wales. Proc. Onions 2002 Conf., Nat. Veg. Ind. Ctr., Yanco Agr. Inst., Yanco, Australia, 3-7 June 2002. p. 31-34.

Randle, W.M. and M.L. Bussard. 1993. Streamlining onion pungency analyses. HortScience 28:60. 


\section{Variety Trials}

Schiavi, M., G. Bonetti, L. Bonomi, S. Cornali, M. Dadomo, and S. Stringa. 2002. Choice of onion varieties. Informatore Agrario 58:69-74.

Silue, S., L. Fondio, M.Y. Coulibaly, and H. Magein. 2003. Selection of varieties onion (Allium cepa L.) adapted to the North of Ivory Coast. Tropicultura 21:129-134.

State of Georgia. 2004. Additional regulations applicable to Vidalia onions, Chapter 40-7-8. 21 Jan. 2005. <http://rules.sos.state.ga.us/cgi-bin/page. cgi? $\mathrm{g}=$ GEORGIA DEPARTMENT OF AGRICULTURE\%2FFOOD_DIVISION_ REGULATIONS\%2FADDITIONAL_ REGULATIONS APPLICABLE TO VIDALIA_ONIONS\%2Findex.html $\& \mathrm{~d}=\bar{l}>$.

USDA. 1995a. United States standards for grades of Bermuda-Granex-Grano type onions. U.S. Dept. Agr. Rpt., USDA, Washington, D.C.

USDA. 1995b. Vegetables final estimates 1987-92. U.S. Dept. Agr. Rptr. NASS Stat. Bul. No. 902.

USDA. 2004. Vegetables 2003 summary. U.S. Dept. Agr. Rpt. Veg. 1-2 (04).

Vasetskii, V.F. and N.G. Reznik. 1990. Varieties for mechanical harvesting. Kartofel' i Ovoshchi. 1:40-41.

Verma, L.R., U.B. Pandey, S.R. Bhonde, and K.J. Srivastava. 1999. Quality evaluation of different onion varieties for dehydration. Nwsl. Natl. Hort. Res. Dev. Foundation 19:1-6.

Wall, M.M. and J.N. Corgan. 1992. Relationship between pyruvate analysis and flavor perception for onion pungency determination. HortScience 27:1029-1030.

Williams, T.V. and W. Roberts. 2002. Is vegetable variety evaluation and reporting becoming a lost art? An industry perspective. HortTechnology 12:553-559.

Zuev, V., N. Bakuras, and T. Osipova. 1974. Onion varieties resistant to salinization. Kartofel' i Ovoshchi 2:19-20. 